\title{
A PREDICTIVE AND COMPARATIVE STUDY VIA VIRAL AND BIOCHEMICAL MEASUREMENTS FOR RESPONDERS AND NON-RESPONDERS EGYPTIAN HEPATITIS C PATIENTS TO DACLATASVIR PLUS SOFOSBUVIR THERAPY
}

\section{BY}

Ahmed R. Sofy ${ }^{1}$, Khalid A. El-Dougdoug ${ }^{2}$, Adel A. Mousa ${ }^{1}$, EL-Sayed H.E. Gawesh ${ }^{3}$, Ahmed A. El-Shamy ${ }^{4}$, Atef S. El-Gebaly ${ }^{1}$ and Ahmed A. Hmed ${ }^{1}$

\section{FROM}

${ }^{1}$ Botany and Microbiology Department, Faculty of Science, Al-Azhar University, 11884 Nasr City, Cairo, Egypt

${ }^{2}$ Virology Laboratory, Agricultural Microbiology Department, Faculty of Agriculture, Ain Shams University, 11241 Cairo, Egypt

${ }^{3}$ Forensic Medicine and Clinical Toxicology Department, Faculty of Medicine, AlAzhar University, Damietta, Egypt

${ }^{4}$ Clinical Pathology Department, Faculty of Medicine, Al-Azhar University, Damietta, Egypt

\begin{abstract}
Most of the liver diseases and hepatocellular carcinoma (HCC) worldwide is due to infection with hepatitis $C$ virus. The developed new drugs in the last few years are promising, but patients response to such drugs are different. Therefore, to identify early the non-responding patients to SOF/DCV therapy for saving of medical costs and to guide them for appropriate treatment without wasting time, HCV RNA in conjunction with biochemical tests were measured during treatment (at week 4) for 100 blood samples from patients were positive for antibodies to (HCV), elevated liver enzymes (mean baseline serum ALT $( \pm$ SD 123 $\pm 2.7 \mathrm{U} / \mathrm{L})$, RT-PCR baseline 355,000 IU/ ml. All patients were negative for hepatitis $B$ virus. These patients were under treatment with DAC $60 \mathrm{mg} /$ day plus Sofosbuvir $400 \mathrm{mg} /$ day to give a predictive outcome of the extent of response or not to this therapy. In addition, the same analyses were performed after the end of course therapy ( 12 weeks) in order to compare the results of the predictive value. The obtained results at week 4 of treatment indicated that $95 \%$ of patients had been shifted to normal range for biochemical analysis measured in addition, viral load was decreased in $95 \%$ of patients, while at the end of treatment course (week 12) biochemical response was completely achieved in $98 \%$ of patients in a complete normalization ranges as well as, viral titer reached to the below detection limit. On the other hand, the rest of the patient samples still abnormal and classified as nonresponding.
\end{abstract}

Keywords: Hepatitis C, Sofosbuvir, Daclatasvir, Responder, Non-responder 


\section{Introduction}

Hepatitis $\mathrm{C}$ virus is one of the most important viruses of the genus Hepacivirus in the family Flaviviridae (Simmonds et al. 2017). About 185 million people all over the world were positive for $\mathrm{HCV}$ and tended to develop hepatocellular carcinoma (HCC) and serious liver disease (Cox 2015). All over the world, Egypt recorded a high level of HCV occurrence (Blach et al. 2017). About $93 \%$ of HCV infection in Egypt due to Genotype 4 (Kamal and Nasser 2008).HCV transmission occurs when the blood of infected person contacts with another person through medical practices for transfusion or injection (Ali et al. 2011; Lavanchy 2011). Antischistosomal therapy is likely to be the leading cause of HCV transmission in Egypt through or reuse or sharing needles (Struthers 2007). Also, through the poor sterilized dental or surgical equipments (Mohamoud et al. 2013). HCV is classified into six major genotypes which vary at least $30 \%$ of its nucleotide sequence. This variation in genetics is a powerful selection mechanism for viral resistance to medicinal drugs or immune system evasion (Kim and Chang 2013). In long-term chronic cases, HCV infection is accompanied by fibrosis, cirrhosis, and ultimately, HCC which consider the major cause of death (Ballester et al. 2005; Struthers 2007: Ruane et al., 2015). More than $85 \%$ of Egyptians infected with HCV are survive, leading to chronic hepatitis (Hoofnagle 1997; Struthers 2007). The development of direct-acting antiviral (DAA) interferonfree oral drugs is the best substitution for interferon therapy (Muir 2014; Ruane et al. 2015). These drugs are more specific to HCV particles, and its mechanism of action depends on attacking the viral enzymes system responsible for RNA replication process, thereby inhibiting viral multiplication (Muir 2014). Some of these drugs improve the sustained virological response (SVR) to100\% with fewer side effects and short duration of therapy at the end of 2013, there were two new direct-acting antiviral (DAA) agents approved for the treatment of HCV infection: namely Sofosbuvir (SOF) (Sulkowski et al. 2014). It is effective and tolerable oral NS5B inhibitor with once-daily dosing for three months (Pol et al.,2016;Abd-Elsalam et al.,2017).

Another effective direct acting antiviral is Daclatasvir is an NS5A inhibitor with once daily dose (Pol et al. 2016). In genotype 1 or 4 patients who are supposed to be difficult in the treatment with interferon showed a high rate of SVR that due to a combination of SOF/DCV and also, improves liver function (Abd-Elsalam et al. 2017; Pol et al. 2016). This type of therapy represents a promised less invasive and novel treatment scheme, which presents a new hope to address and stop the spread of HCV in Egypt. However, non-responding patients to this treatment are known after the completion of course therapy ( 3 months) which leads to medical loss as well as, wasting time on these patients to receive the appropriate treatment so as not to worsen their health. Therefore, the main goal of our study is to predict early the responders and nonresponders of Egyptian hepatitis $\mathrm{C}$ genotype 4 patients under a combination of SOF/DCV therapy via the results of measurements of biochemical and viral analyses (four weeks), and the comparison with the same measurements at the end of course therapy (12 weeks). 


\section{Materials and Methods}

\section{Patient's samples criteria}

This study was conducted on the samples from 100 patients who were referred to Menoufia hospital, from Menoufia governorate in the period from March 2016 to May 2017 with the following inclusion criteria:

All patient's samples were positive for antibodies to hepatitis $\mathrm{C}$ virus (HCV) using a second-generation enzyme-linked immunosorbent assay (ELISA), elevated liver enzymes [ mean baseline serum ALT (MSD 123 $\pm 2.7 \mathrm{U} / \mathrm{L}$ )], and RT-PCR ( baseline $355,000 \mathrm{IU} / \mathrm{ml}$ ). All the patients were under Sofosbuvir $400 \mathrm{mg} /$ day plus DAC 60 $\mathrm{mg}$ /day therapy. Age distribution ranged between 21-65 years (Mean $\pm \mathrm{SD}, 43 \pm 8.5$ ), type of gender among patient's samples was 43 males (43\%), and 57 females $(57 \%)$ and urban were 45 patient's samples, and rural were 55 . The exclusion criteria were: non-B hepatitis infection, no cirrhosis, and non-HCC.

\section{Sample collection}

Under complete aseptic technique $\sim 10 \mathrm{ml}$ venous blood withdrawn from the cubital vein and divided into three aliquots:

First aliquot: $1.5 \mathrm{ml}$ of blood was added to the EDTA tube for complete blood count (CBC). Second aliquot: $1.8 \mathrm{ml}$ of blood was added to citrated tube for prothrombin time (PT) and international normalized ratio (INR). Third aliquot: remaining of blood was added to plain tube and incubated $20 \mathrm{~min}$ at $37^{\circ} \mathrm{C}$ and then centrifuged and supernatant serum was used for biochemical and the viral measurements, including serum glutamic-oxaloacetic transaminase (SGOT), serum glutamic pyruvic transaminase (SGPT), albumin (ALB), bilirubin (BIL) in addition virological analysis for HCV RNA (RT-PCR) to assess the quantity of the virus in the blood.

\section{Serological detection of $\mathrm{HCV}$}

HCV-ELISA test (third-generation Murex anti-HCV version III, VK 47) Murex Kit was performed for all serum samples. Plate with 96 well coated with HCV recombinant antigen-loaded with diluted samples and controls was incubated for one hour at $37^{\circ} \mathrm{C}$. Then the conjugate was added after washing the plate. The plate was then incubated at $37^{\circ} \mathrm{C}$ for $30 \mathrm{~min}$. After incubation, the washing step was repeated, and then the reaction was visualized using a TMB substrate solution (colorimetric microwell substrates). The reaction was stopped using $\mathrm{H}_{2} \mathrm{SO}_{4}$. The color intensity was measured by spectrophotometer at $450 \mathrm{~nm}$ (Multiscan "Plus" DASIT SPA) (Courouce 1998).

\section{Biochemical measurements}

For SGPT or SGOT assay: Diammond Kit was use .briefly: $0.1 \mathrm{ml}$ of serum or blank was added to $0.5 \mathrm{ml}$ of SGPT or SGOT reagent (A) incubated for $30 \mathrm{~min}$ at $37^{\circ} \mathrm{C}$, then $0.5 \mathrm{ml}$ of SGPT or SGOT reagent (B) was added to the reaction, mixed well and incubated again for 20 minutes at $37^{\circ} \mathrm{C}$. At the end of the incubation period, $5 \mathrm{ml}$ of sodium hydroxide was added to the reaction mixture and left for $5 \mathrm{~min}$ at room temperature, and then measured at $546 \mathrm{~nm}$ (Reitman and Frankel, 1957). 
For total bilirubin assay: Diammond Kit was use .one $\mathrm{ml}$ of reagent (3) was mixed with $0.05 \mathrm{ml}$ of reagent (2), and $0.2 \mathrm{ml}$ of reagent (1), then $0.2 \mathrm{ml}$ of serum sample/or blank was added in the test tube, mixed well and incubated for $10 \mathrm{~min}$ at 20$25^{\circ} \mathrm{C}$. Finally, one $\mathrm{ml}$ of reagent (4) was added, and the developed color intensity was measured at $578 \mathrm{~nm}$ (Burits et al., 1999).

For albumin assay: Diammond Kit was use ten (10) $\mu$ l of sample and standard were incubated in tow tubes then $2.5 \mathrm{ml}$ of reagent (2) were added to each tube and mixed well, incubated for $10 \mathrm{~min}$ at $15-20^{\circ} \mathrm{C}$ and read the absorbance of the samples and standard against the blank(Gendler et al., 1984).

For prothrombin assay:Siemens (thromborel S ) kit . one hundred (100) $\mu \mathrm{l}$ of citrated plasma was pipetted into prewarmed tube at $37^{\circ} \mathrm{C}$, then incubated for one min at $37^{\circ} \mathrm{C}, 200 \mu \mathrm{l}$ of PT reagent warmed at $37^{\circ} \mathrm{C}$, then added to the tested plasma and press on timer to calculate the time for coagulation and calculate the concentration and INR (international normalization ratio) (Wagner and Dati, 1998). For determining the haematological parameters (Haemoglobin, white blood cells, and platelets), a quantitative automated analyzer system XS-1000i was used.

\section{Viral measurements}

\section{RNA extraction}

By using QIAamp Viral RNA Mini kit .RNA was extracted using a viral RNA mini kit containing [binding solution, Wash Buffer (1), Wash Buffer (2) and Elution Buffer $(\mathrm{R})]$. The procedure was conducted according to the instructions included with the kit. Briefly, $0.2 \mathrm{ml}$ double distilled water and $0.2 \mathrm{ml}$ of sample was transferred into an extraction tube, incubated in a thermomixer at $65^{\circ} \mathrm{C}$ for 15 minutes, and $10 \mathrm{~min}$ at $95^{\circ} \mathrm{C}$. Then $0.4 \mathrm{ml}$ of binding solution was added and mixed well to each sample. RTA Spin Filter was incubated for one minute with sample and centrifuged for $120 \mathrm{sec}$ at $11.000 \mathrm{rpm}$; the flow was then castaway and RTA Spin Filter was transferred to a new RTA receiver tube. A $0.5 \mathrm{ml}(\mathrm{R} 1)$ solution was added then centrifuged at $11.000 \mathrm{rpm}$ for $60 \mathrm{sec}$, the flow was then castaway, and RTA Spin Filter was transferred to a new RTA receiver, and the previous step was then repeated using $0.7 \mathrm{ml}(\mathrm{R} 2)$ washing solution. After that, RTA Spin Filter was transferred into RNase-free $1.5 \mathrm{ml}$ elution tube, $60 \mu$ of a preheated elution buffer (R) to $65^{\circ} \mathrm{C}$ was pipetted onto the membrane of the RTA Spin Filter, incubated for $3 \mathrm{~min}$, and then centrifuged at $11.000 \mathrm{rpm}$ for $1 \mathrm{~min}$. Finally, the RTA Spin Filter was discarded, and the eluting solution containing viral RNA was incubated in ice (Kleiber et al. 2000).

\section{Real Time PCR (RT-PCR)}

The HCV RNA was quantified using the Stratagene' Mx3000P quantitative RTPCR system. The kit is containing reagents and enzymes responsible for amplification of targeted sites located within $5^{\prime}$ noncoding region of the HCV RNA genome and fluorescence detector FAM (reporter dye) in addition to reverse transcription enzymes and $\mathrm{MgCl}_{2}$. A specific primer KY78 (5'CTCGCAAGCACCCTATCAGGCAGT) and KY80 (5'GCAGAAAGCGTCTAGCCATGGCGT) targeting the 244-base region located within the highly conserved 5' noncoding region of the HCV genome. At first, reverse transcriptase was used to reverse transcribe cDNA from RNA. To achieve that, the reaction mixture containing the sample and transcriptase enzyme was incubated for one hour at $40^{\circ} \mathrm{C}$. The next step was the activation of AmpliTaq gold for 3 min at $95^{\circ} \mathrm{C}$. 
The formed double helix was denatured at $95^{\circ} \mathrm{C}$ for $15 \mathrm{sec}$ followed by annealing at $94^{\circ} \mathrm{C}$ for $5 \mathrm{sec}$, then the extension was occurred at $62^{\circ} \mathrm{C}$ for $10 \mathrm{sec}$ leaving fluorescence endpoint detector. The detector intensity increases as the cycle's number increased. The computer software system connected to the apparatus permit real-time view and analyzes the plots during the run of PCR (Kleiber et al. 2000).

\section{Response definition}

\section{Biochemical response}

The biochemical response is a shift to normal values at week 4 during treatment and reaching to the normalization of all biochemical values measured after finishing the treatment course (week 12). While biochemical non-responders who were showed abnormal biochemical values at the two previous times of measurements. Biochemical normal ranges in our study were ALT (Alanine aminotransferase ) $\leq 44 \mathrm{U} / \mathrm{L}$, AST(Aspartate aminotransferase) $\leq 38 \mathrm{U} / \mathrm{L}$, ALB (Albumin) $(3.5$ - 5.5) g/dL, Bilirubin $\leq 1.0 \mathrm{mg} / \mathrm{dL}$ after, and INR(international normalization ratio) 1 is the standard measure for assessment. In addition, the reference ranges of haematological parameters were HB(Hemoglobin) \% unit (12-16 G/dl), TLC(Total leucocytic count) (4000-11000 cells/cmm), and PLT (Platelet) count (150000-450000 cells/cmm).

\section{Viral response}

The viral response was adopted as a decrease in the viral titer (detection limit of PCR test is $35 \mathrm{IU} / \mathrm{ml}$ ), during treatment at week 4, while complete response considered as a complete absence of viral RNA in the blood of the patients at the end of course therapy (3 months). Non-responder patients had no marked decreases in a viral titer at week 4 as well as, a positive serum HCV RNA tests at week 12.

\section{Statistical analysis}

Statistical analysis was done using the Statistical Package for the Social Sciences (SPSS software version 25, Chicago, Illinois). The methods used for statistical analysis were as follows:

\section{Descriptive statistics}

Mean Standard deviation ( \pm SD) and range for parametric numerical data, while the Median was used for non-parametric numerical data. Standard deviation is the ideal measure of variability and is usually expressed as plus and minus values $( \pm)$ to follow the arithmetic mean of the sample.

\section{Analytical statistics}

Student t-test was used to assess the statistical significance of the difference between the two-study group means values of quantitative data.

Mann Whitney Test ( $\mathrm{U}$ test) was used to assess the statistical significance of the difference of a non-parametric variable between two study groups.

Pearson Correlation Test was used to examine the relationship between two quantitative variables. 
P-value: level of significance

- $P>0.05$ : No significant (NS).

$-P<0.05$ : Significant $(\mathrm{S})$.

- $P<0.01$ : Highly significant (HS).

\section{Results}

\section{Prediction of response to DCV+SOF therapy at week 4}

Analysis of characteristics (biochemical and viral measurements) during treatment (week 4) and its comparison with pre-treatment baseline data of measurements may help in predicting responding and non-responding patients. Data presented in table (1) show the comparison between the results of expected responder and non-responder patients of biochemical, haematological, and molecular tests during treatment.

Table 1. Biochemical, haematological, and molecular tests after 4 weeks of treatment (prediction of responding and non-responding patients)

\begin{tabular}{|c|c|c|c|c|}
\hline \multicolumn{2}{|r|}{ Test } & Responder & Non-responder & P-value \\
\hline ALT & Median (IQR) & $\begin{array}{c}31.00 \mathrm{U} / \mathrm{L} \\
(27.75-39.00)\end{array}$ & $\begin{array}{c}66.00 \mathrm{U} / \mathrm{L} \\
(54.75-89.00)\end{array}$ & $<0.001 \mathrm{HS}$ \\
\hline AST & Median (IQR) & $\begin{array}{c}32.50 \mathrm{U} / \mathrm{L} \\
(28.75-36.00)\end{array}$ & $\begin{array}{c}62.00 \mathrm{U} / \mathrm{L} \\
(49.00-79.75)\end{array}$ & $<0.001 \mathrm{HS}$ \\
\hline Bili & Median (IQR) & $\begin{array}{l}1.00 \mathrm{mg} / \mathrm{dL} \\
(0.800-1.10)\end{array}$ & $\begin{array}{l}1.50 \mathrm{mg} / \mathrm{dL} \\
(1.30-1.70)\end{array}$ & $<0.001 \mathrm{HS}$ \\
\hline ALB & Mean \pm SD & $4.11 \pm 0.46 \mathrm{~g} / \mathrm{dL}$ & $3.39 \pm 0.56 \mathrm{~g} / \mathrm{dL}$ & $<0.001 \mathrm{HS}$ \\
\hline INR & Median (IQR) & $\begin{array}{c}1.00 \\
(1.00-1.02)\end{array}$ & $\begin{array}{c}1.18 \\
(1.14-1.25)\end{array}$ & $<0.001 \mathrm{HS}$ \\
\hline $\mathrm{HB}$ & Median (IQR) & $\begin{array}{c}12.90 \mathrm{G} / \mathrm{dl} \\
(12.50-13.15)\end{array}$ & $\begin{array}{c}11.85 \mathrm{G} / \mathrm{dl} \\
(11.30-12.40)\end{array}$ & $<0.001 \mathrm{HS}$ \\
\hline TLC & Median (IQR) & $\begin{array}{c}5100.00 \\
(4537.50-5625.00)\end{array}$ & $\begin{array}{c}4100.00 \\
(3670.00-4512.50)\end{array}$ & $<0.001 \mathrm{HS}$ \\
\hline PLT & Median (IQR) & $\begin{array}{c}215500.00 \\
(194000.00-263250 .)\end{array}$ & $\begin{array}{c}144500.00 \\
(138750.0-156250.0)\end{array}$ & $<0.001 \mathrm{HS}$ \\
\hline PCR & Median (IQR) & $\begin{array}{c}61500.00 \\
(31750.00-136000.0)\end{array}$ & $\begin{array}{c}257000.00 \\
(129500.0-364000.0)\end{array}$ & $<0.001 \mathrm{HS}$ \\
\hline
\end{tabular}

After 4 weeks of treatment, ALT in responder patients showed significant reduction and dropped in concentration near to normal range recording about $31 \mathrm{U} / \mathrm{L}$ while, in non-responder patients showed minimal reduction reached about $66 \mathrm{U} / \mathrm{L}$ in ALT concentration (Figure 1). 


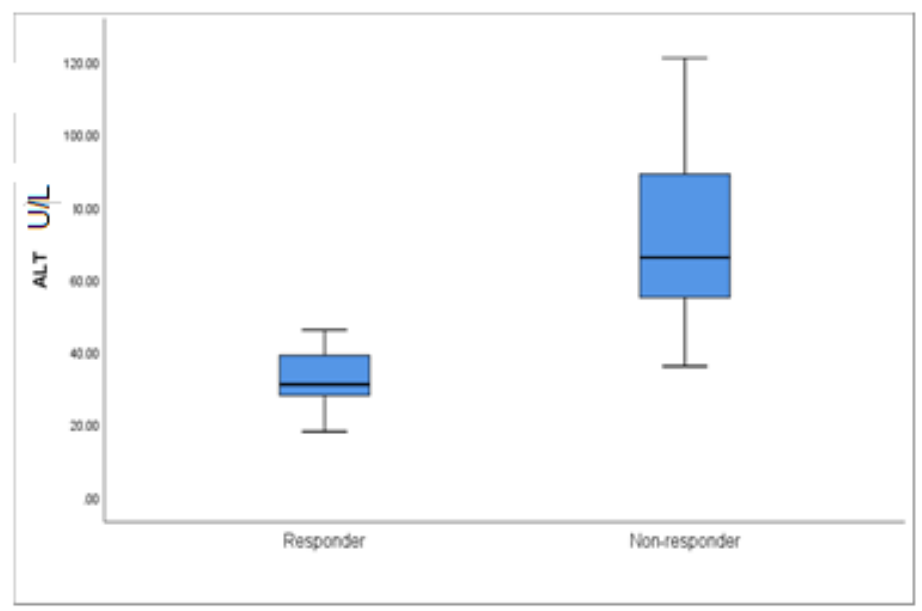

Figure 1. Comparison between groups responders and non-responder regarding ALT during treatment

As well as, AST in responder patients was $32.5 \mathrm{U} / \mathrm{L}$ showed significant reduction and dropped to the normal range as a result of treatment with DCV+SOF. While in nonresponder patients was $62 \mathrm{U} / \mathrm{L}$ showed a minimal reduction in AST concentration (Figure 2).

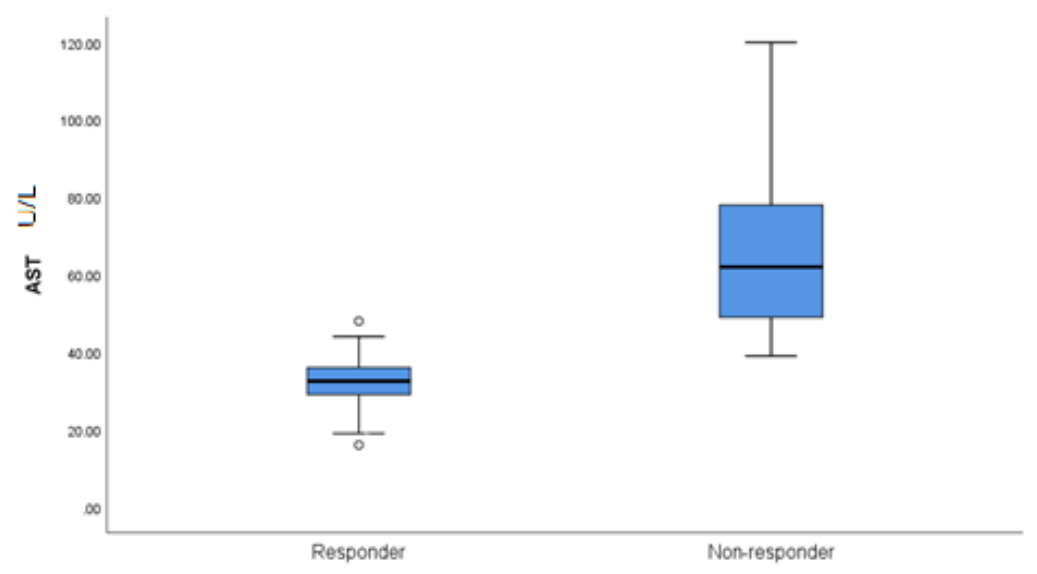

Figure 2. Comparison between groups responder and non-responder regarding AST during treatment

During treatment, bilirubin in responder patients was $1.0 \mathrm{mg} / \mathrm{dL}$, which showed improvement by the treatment in contrast to non-responder patients whose showed a significant increase in bilirubin $1.5 \mathrm{mg} / \mathrm{dL}$ during treatment (Figure 3). 


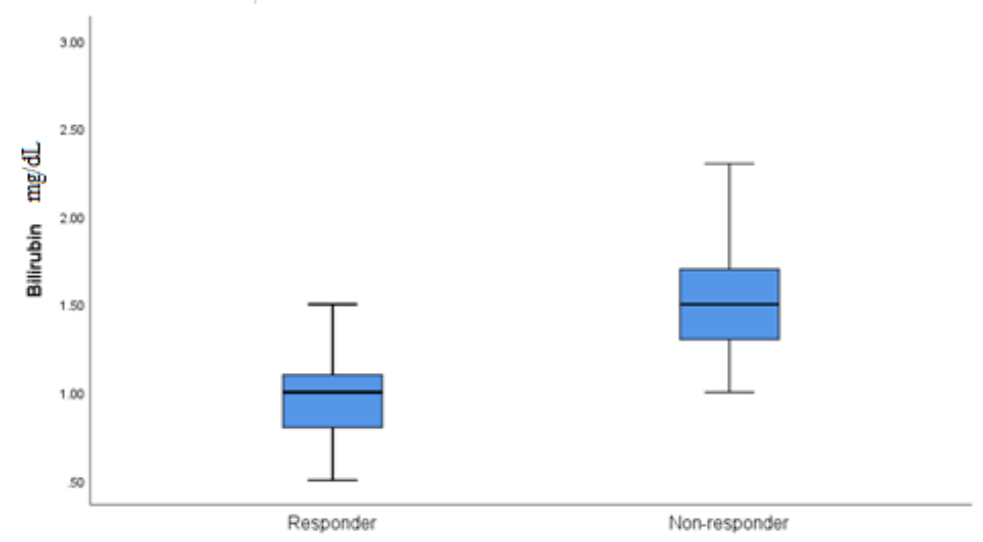

Figure 3. Comparison between groups responder and non-responder regarding bilirubin during treatment

Albumin in responder patient was $4.11 \pm 0.46 \mathrm{~g} / \mathrm{dL}$ with no tangible effect on synthesis of albumin by the liver in contrast to non-responder patients there was a significant effect on albumin concentration $3.39 \pm 0.56 \mathrm{~g} / \mathrm{dL}$ with minimal decrease than showed in responder patients as shown in (Figure 4).

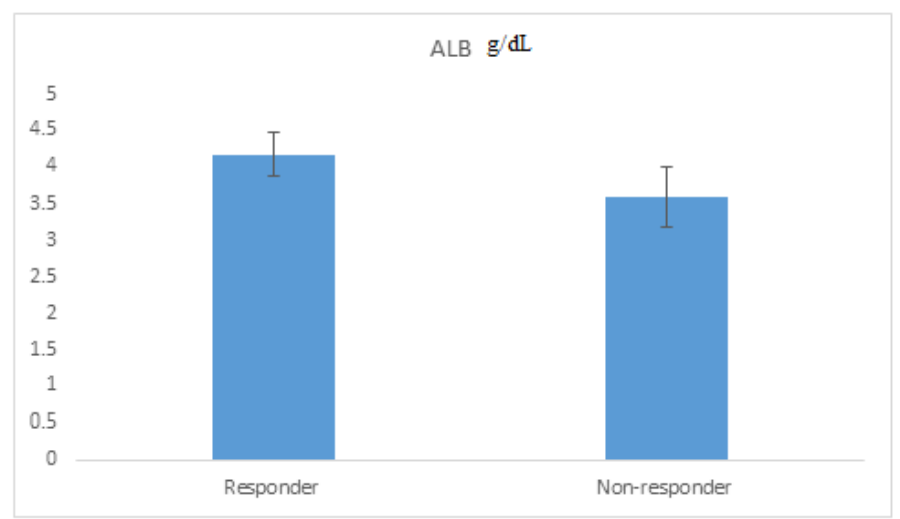

Figure 4. Comparison between groups responder and non-responder regarding ALB during treatment

INR in responder patients during treatment was 1.0 showed normal range while in non-responder patients, INR was about 1.18 as shown in figure (5). 


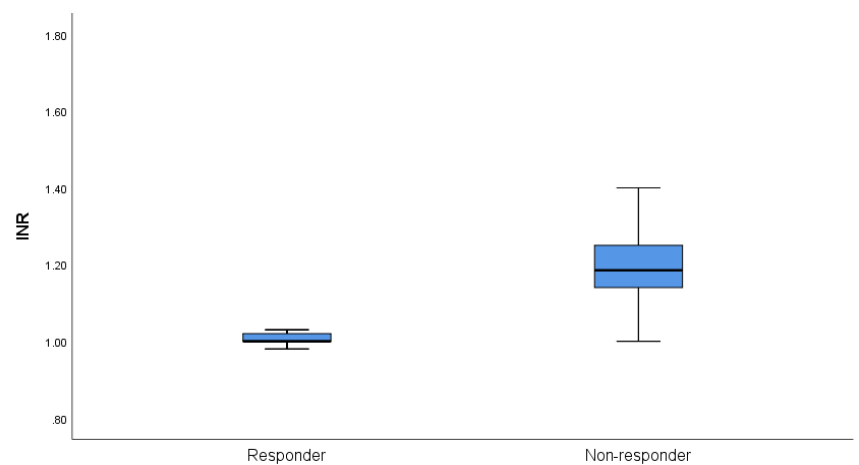

Figure 5. Comparison between groups responder and non-responder regarding INR during treatment

In responder patients, haemoglobin concentration was $12.90 \mathrm{G} / \mathrm{dl}$ with no significant evidence for occurring of anemia while in non-responder patients, there was a decrease in haemoglobin concentration $11.85 \mathrm{G} / \mathrm{dl}$ as shown in figure (6).

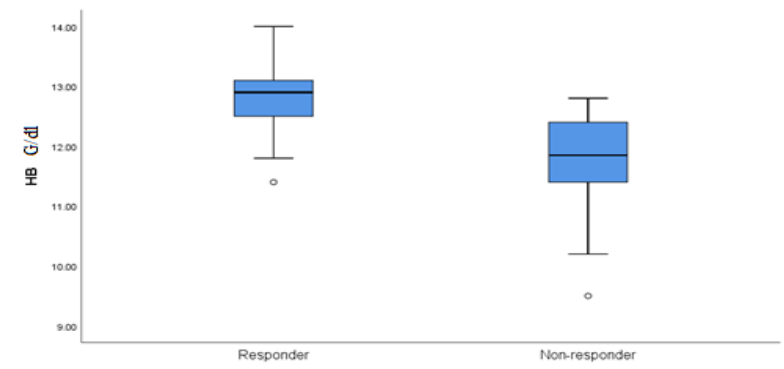

Figure 6. Comparison between groups responder and non-responder regarding HB during treatment

TLC in responder patients was 5100 slightly located between normal range during treatment while in non-responder patients, TLC was 4100 and tended to slight decreasing in number, as shown in figure (7).

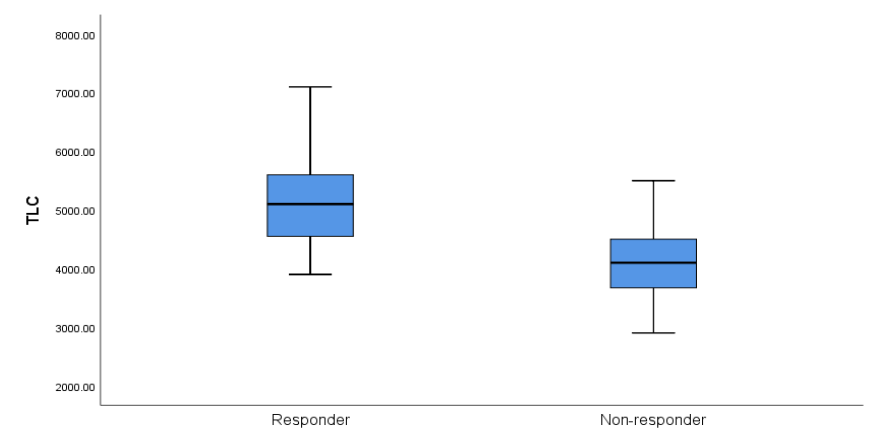

Figure 7). Comparison between groups responder and non-responder regarding TLC during treatment 
As well as, platelets count in responder patients was in the normal range 215500 while in non-responder patients' platelets count was 144500 and tended to cause thrombocytopenia with more decreasing in number as shown in figure (8).

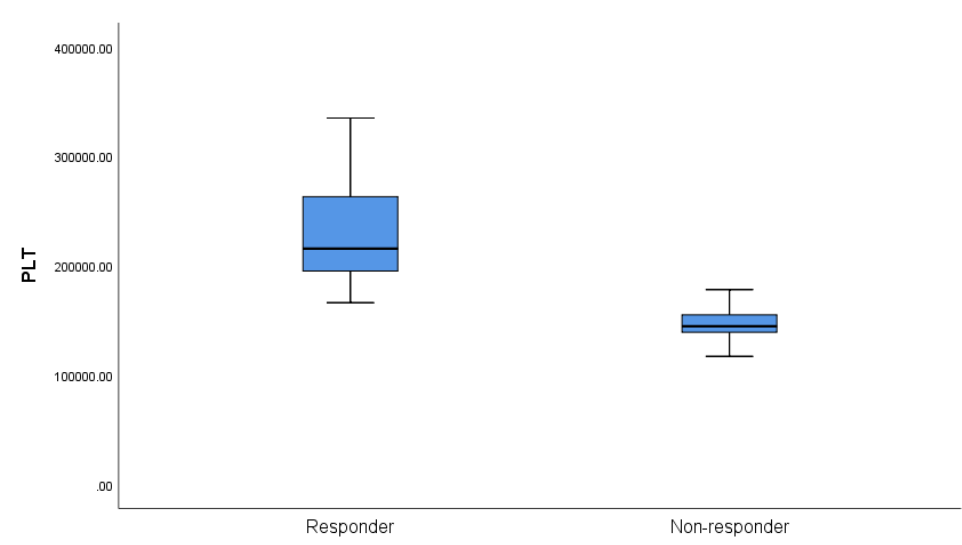

Figure 8. Comparison between groups responder and non-responder regarding PLT during treatment

From table (1) it was found that, SOF/DCV therapy showed marked decrease of viral load after 4 weeks who are expected to be responders to treatment and subsequently, they may show absence of virus at the end of course therapy (after 12 weeks) while in non-responder patients amount of virus still present as shown in figure (9).

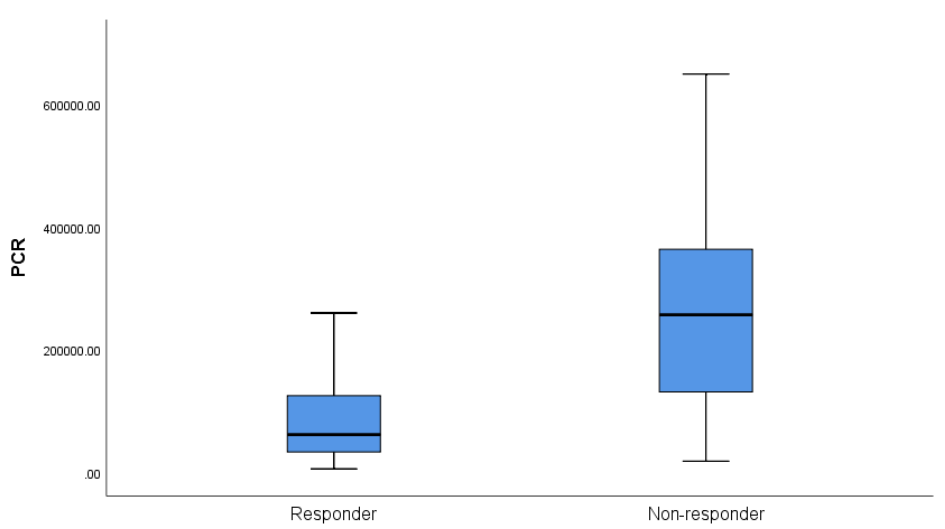

Figure 9. Comparison between groups responder and non-responder regarding RT-PCR during treatment

The end-treatment (week 12) observation measurements

At the end of the 12 weeks of course therapy, the same previous measurements were performed on samples from the same patients for comparison the obtained data with the previous results obtained during treatment in order to confirm this prediction or not. The results presented in table (2) showed the comparison between the results of responder and non-responder patients of biochemical, haematological and molecular tests after the treatment course. Since these results indicated that, the values are moving in the same direction as well as, support the values obtained during treatment. 
Table 2. Comparison between the result of responder and non-responder patients of biochemical, haematological, and molecular tests after the end of treatment (week 12)

\begin{tabular}{|c|c|c|c|c|}
\hline Test & & Responder & Non-Responder & P-value \\
\hline ALT & Median (IQR) & $\begin{array}{l}19.00 \mathrm{U} / \mathrm{L} \\
(16-23.25)\end{array}$ & $\begin{array}{l}47.00 \mathrm{U} / \mathrm{L} \\
(41-55.00)\end{array}$ & $<0.001 \mathrm{HS}$ \\
\hline AST & Median (IQR) & $\begin{array}{l}17.50 \mathrm{U} / \mathrm{L} \\
(14-20.00)\end{array}$ & $\begin{array}{l}46.00 \mathrm{U} / \mathrm{L} \\
(39.00-54.50)\end{array}$ & $<0.001 \mathrm{HS}$ \\
\hline Bili & Median (IQR) & $\begin{array}{c}0.75 \mathrm{mg} / \mathrm{dL} \\
(0.60-0.90)\end{array}$ & $\begin{array}{l}1.19 \mathrm{mg} / \mathrm{dL} \\
(1.10-1.35)\end{array}$ & $<0.001 \mathrm{HS}$ \\
\hline ALB & Mean \pm SD & $4.17 \pm 0.38 \mathrm{~g} / \mathrm{dL}$ & $3.61 \pm 0.41 \mathrm{~g} / \mathrm{dL}$ & $<0.001 \mathrm{HS}$ \\
\hline INR & Median (IQR) & $\begin{array}{l}1.00 \\
(1.00-1.01) \\
\end{array}$ & $\begin{array}{c}1.056 \\
(1.00-1.13) \\
\end{array}$ & $<0.001 \mathrm{HS}$ \\
\hline $\mathrm{HB}$ & Mean \pm SD & $13.47 \pm 1.02 \mathrm{G} / \mathrm{dl}$ & $12.88 \pm 0.84 \mathrm{G} / \mathrm{dl}$ & $<0.001 \mathrm{HS}$ \\
\hline TLC & Median (IQR) & $\begin{array}{r}5450.00 \\
(4870.50-6400.00)\end{array}$ & $\begin{array}{c}5200.00 \\
(4362.00-5825.50)\end{array}$ & $0.018 \mathrm{~S}$ \\
\hline PLT & Median (IQR) & $\begin{array}{c}315000.00 \\
(220000.0-410000.0)\end{array}$ & $\begin{array}{c}14100.00 \\
(138750-279000.0)\end{array}$ & $<0.001 \mathrm{HS}$ \\
\hline PCR & Median (IQR) & Below detection limit & $\begin{array}{c}114500.0 \\
(14000.0-215000.0)\end{array}$ & $<0.001 \mathrm{HS}$ \\
\hline
\end{tabular}

ALT was $19.0 \mathrm{U} / \mathrm{L}$ in responder patients and its concentration return to the normal range, but in non-responder patients, ALT was $47 \mathrm{U} / \mathrm{L}$ with low significant different with responding patient values as shown in figure (10).

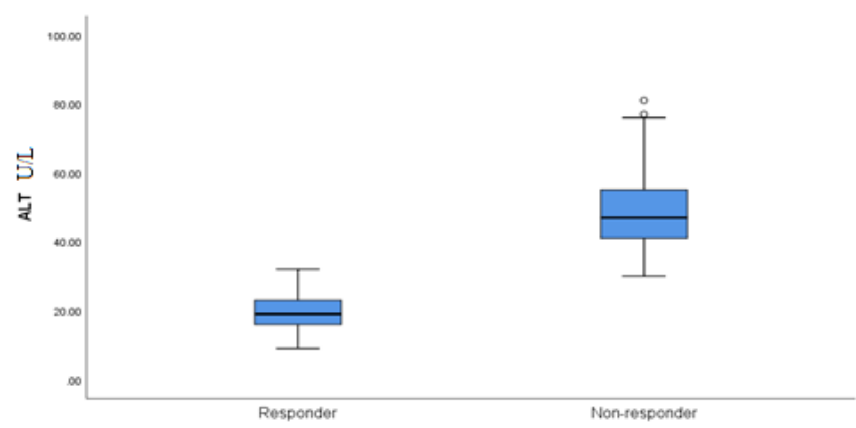

Figure 10. Comparison between groups responder and Non-responder regarding ALT after treatment

Also, it was found that AST returns to normal range $17.5 \mathrm{U} / \mathrm{L}$ in responder patients, but in non-responder patients was $46 \mathrm{U} / \mathrm{L}$ with a low significant increase in the concentration as shown in figure (11). 


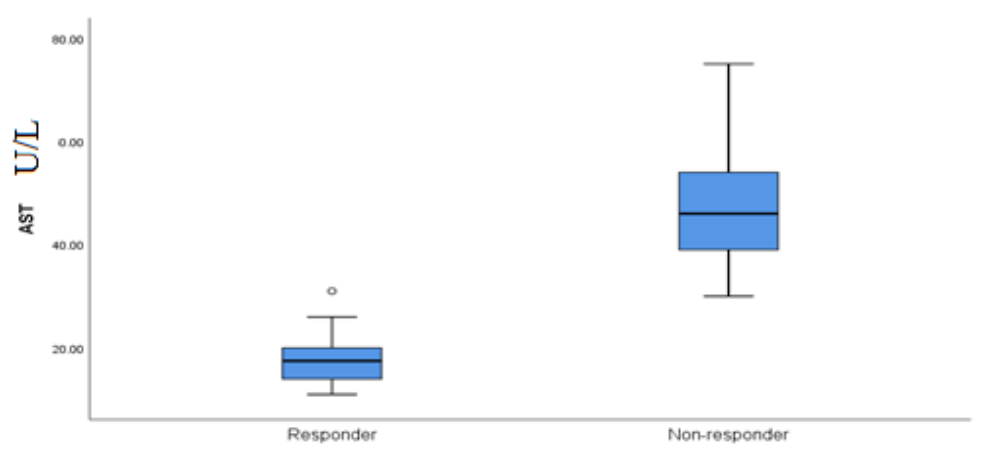

Figure 11. Comparison between groups responder and non-responder regarding AST after treatment

Bilirubin was $0.75 \mathrm{mg} / \mathrm{dL}$ in responder patients in normal range with $100 \%$ recovery, but in non-responder patients was $1.19 \mathrm{mg} / \mathrm{dL}$ with mild increase than in responding patients as in figure (12).

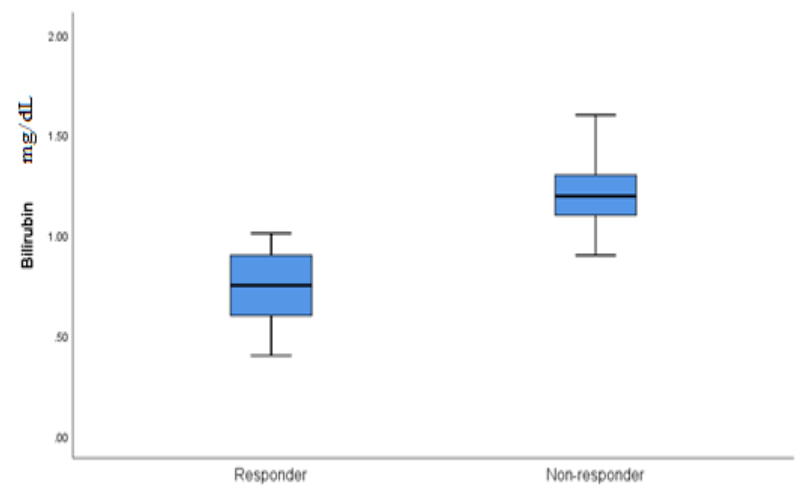

Figure 12. Comparison between groups responder and non-responder regarding bilirubin after treatment

Albumin concentration was $4.17 \pm 0.38 \mathrm{~g} / \mathrm{dL}$ mainly in the normal range, but in non-responder patients was $3.61 \pm 0.41 \mathrm{~g} / \mathrm{dL}$ which located in the low normal range, as shown in figure (13). 


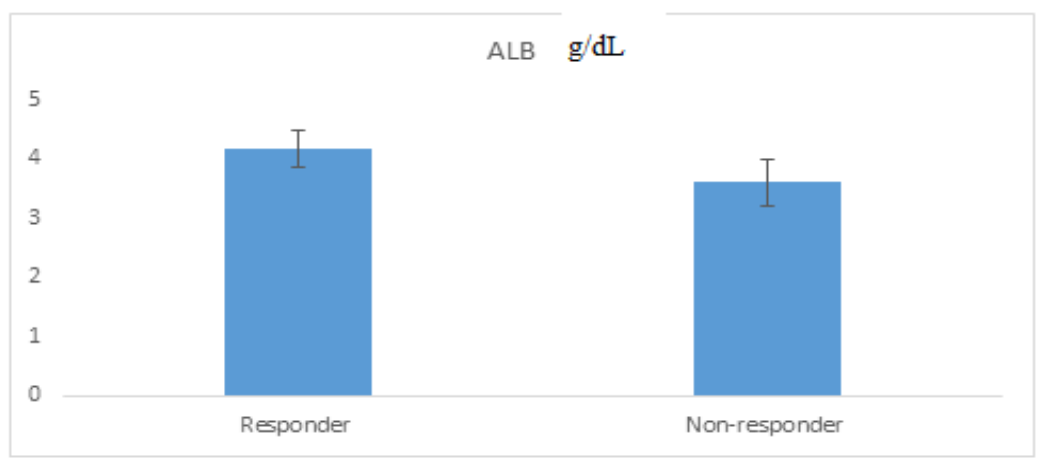

Figure 13. Comparison between responder and non-responder patients regarding ALB after treatment

After treatment, INR was 1.0 in responding patients with complete recovery rate due to coagulation factors produced from healthy liver cells, but in non-responding patients was 1.056 with mild prolonged value compared to that present in responding patients as shown in figure (14).

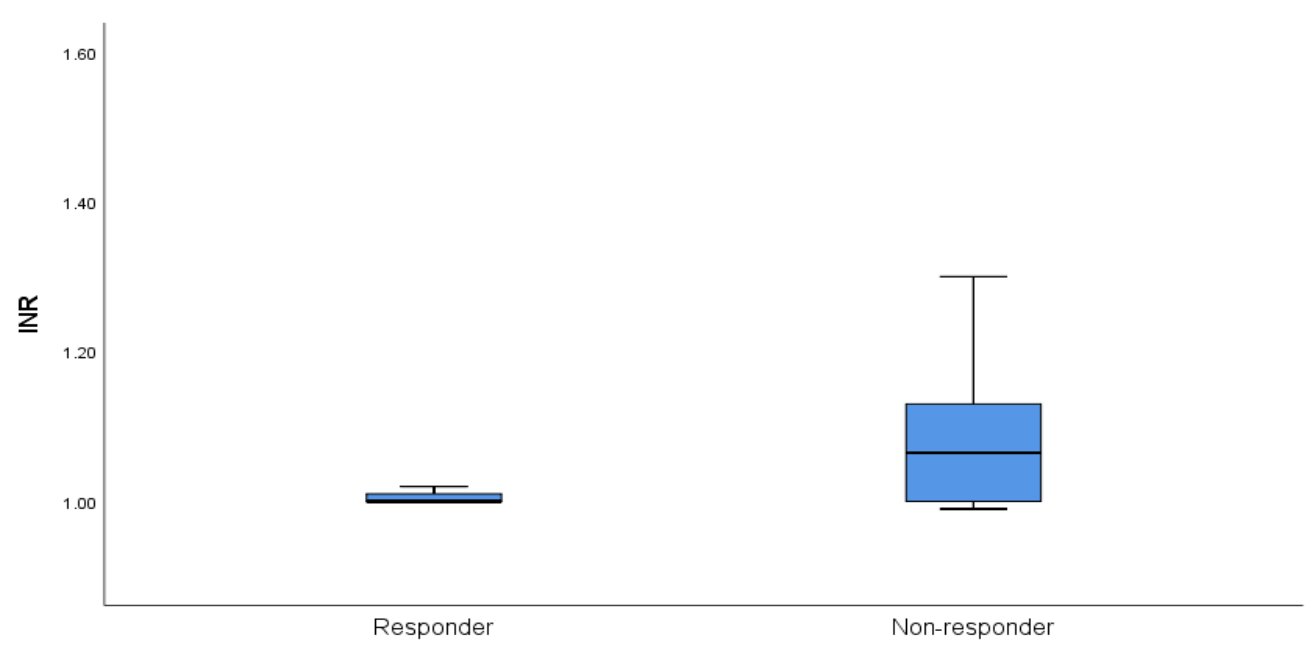

Figure 14. comparison between groups responder and non-responder regarding INR after treatment

The mean of haemoglobin in responder after treatment was $13.47 \pm 1.02 \mathrm{G} / \mathrm{dl}$, but in non-responder was $12.88 \pm 0.84 \mathrm{G} / \mathrm{dl}$, as shown in figure (15). 


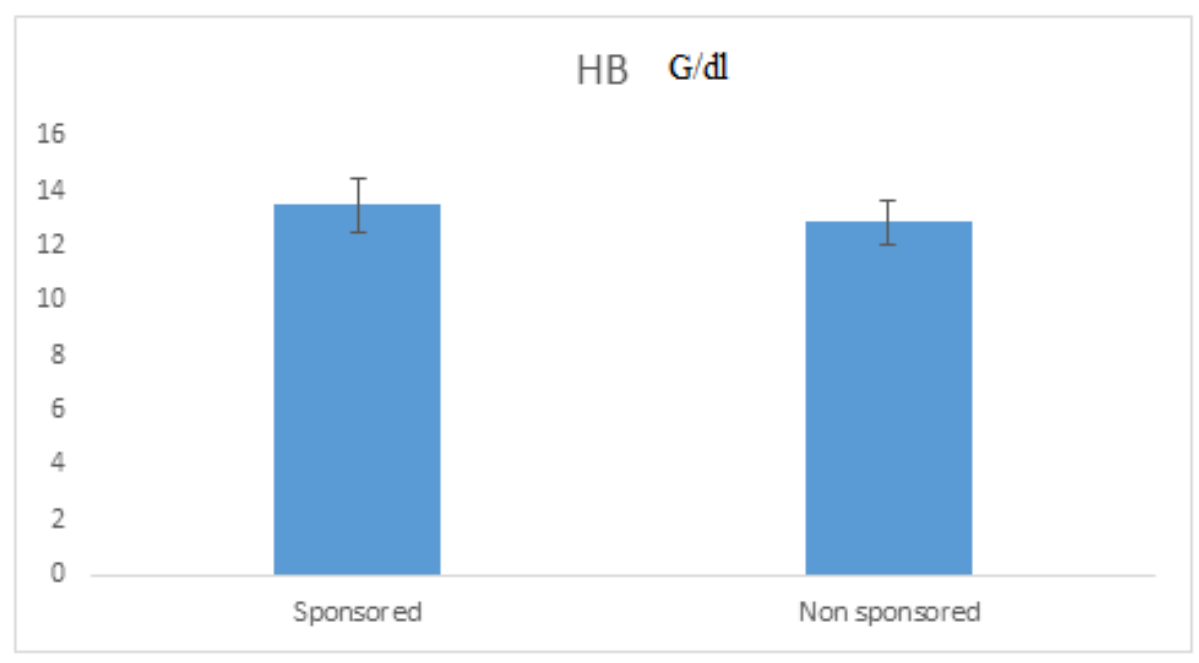

Figure 15. Comparison between responder and non-responder patients regarding HB after treatment

As well as, TLC measured in responder patients was 5450, while in nonresponder patients was 5200 which located in the normal range and without any marked difference between responder and non-responder as shown in figure (16).

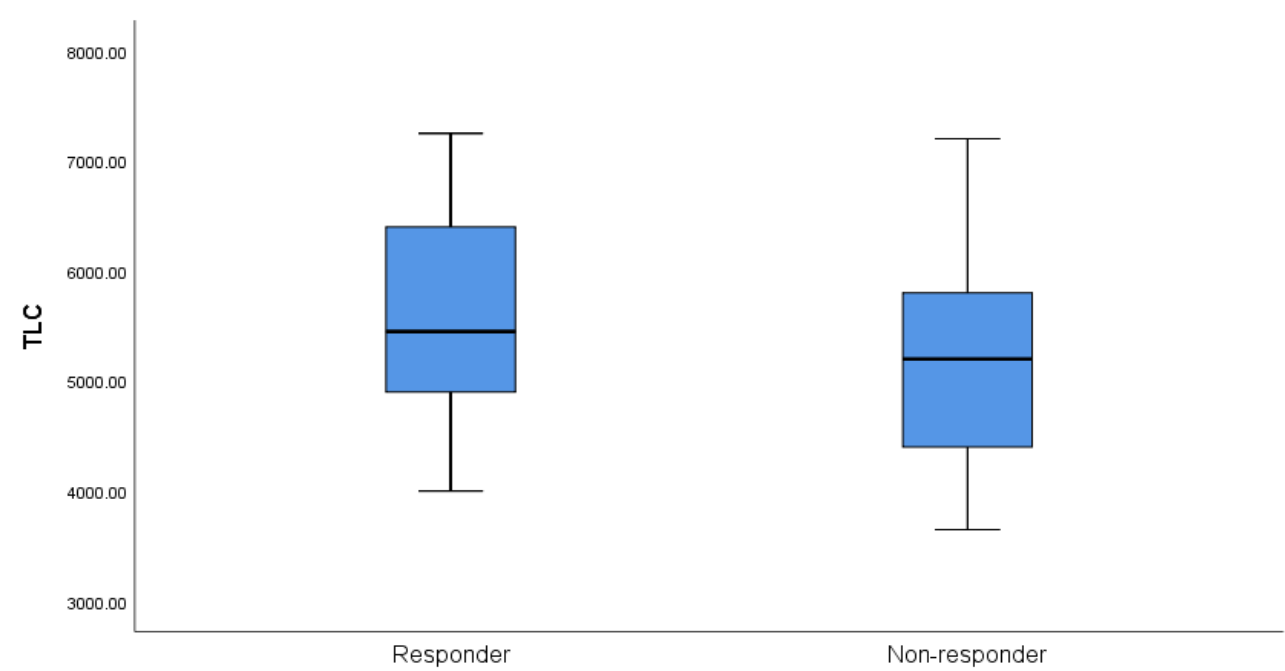

Figure 16. Comparison between responder and non-responder patients regarding TLC after treatment

Platelets count in responder patients was 315000 with marked increase than at during treatment, while in non-responder patients was 141000 with minimal decrease than in normal range, as shown in figure (17). 


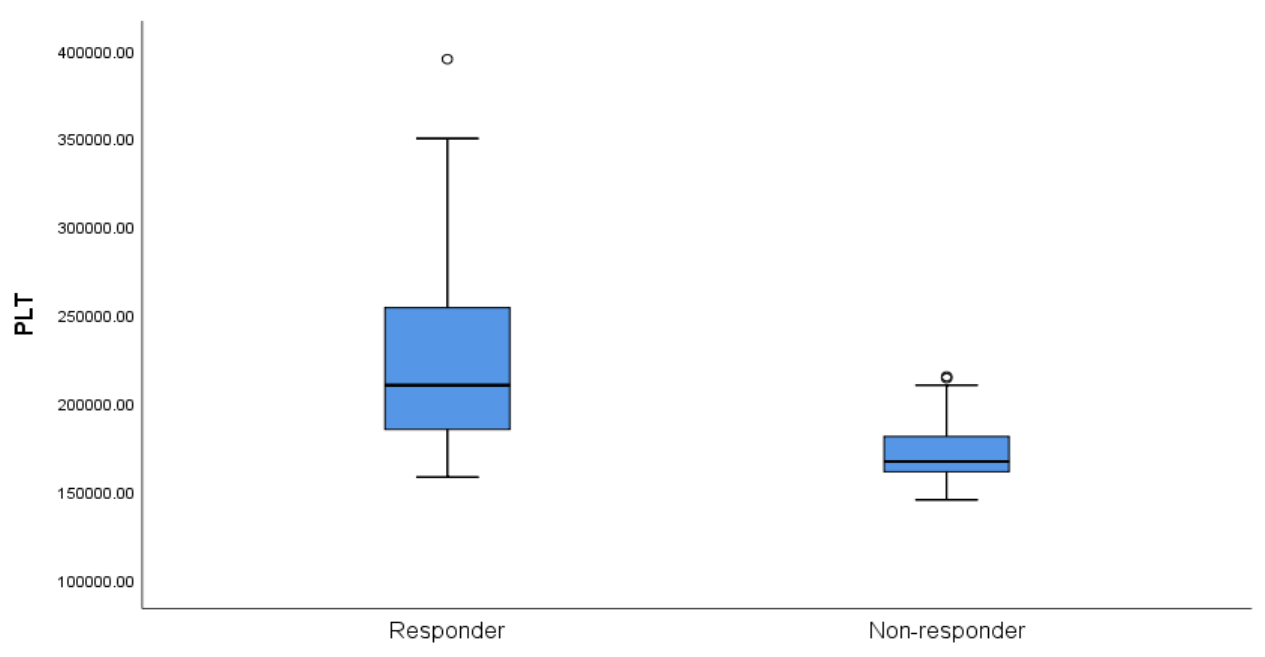

Figure 17. Comparison between responder and non-responder patients regarding PLT after treatment.

After the end of the treatment course, SOF/DCV therapy showed a great ability to altogether remove the viral particles in some patient samples who are responders to the treatment with a percentage of 98 . While in the rest of the patients $(2 \%)$, the virus found in their samples is not responding to this treatment, as shown in figure (18).

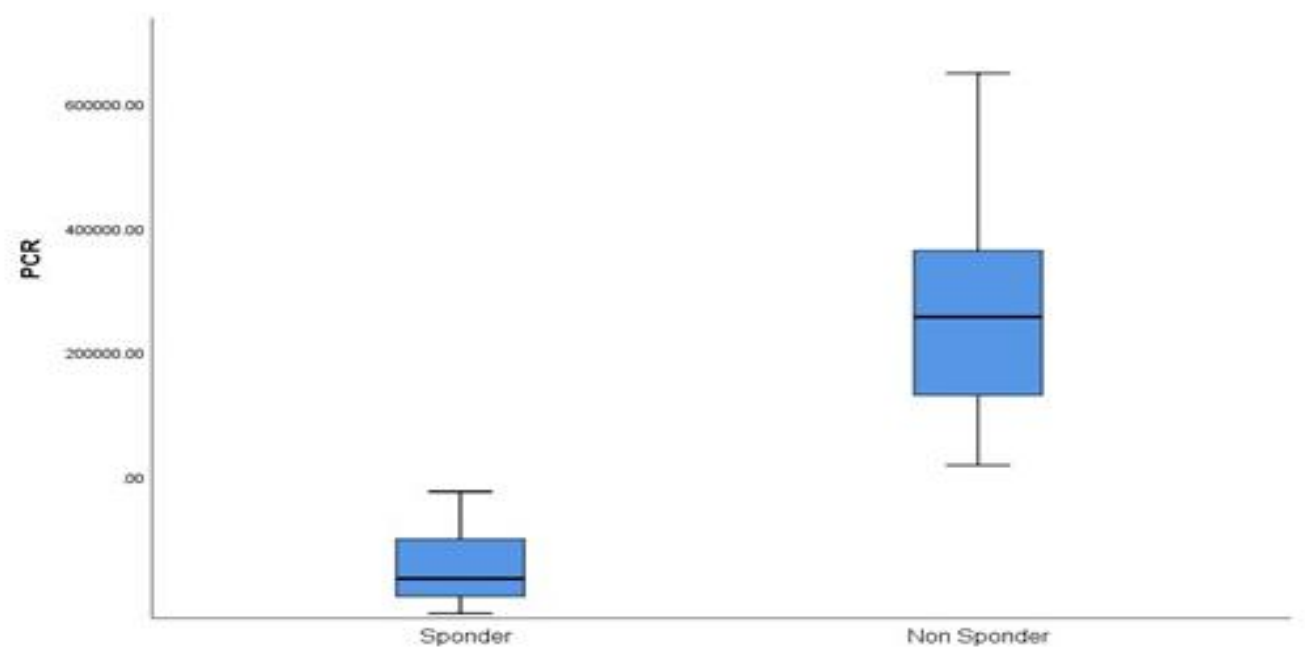

Figure 18. Comparison between responder and non-responder patients regarding RT-PCR after treatment

Of all the above, it turns out that the predictive response value during treatment at week 4 was $95 \%$, while the non-responding was $5 \%$. On the other hand, at the end of course therapy, confirmatory measurements were performed and exhibited a response value was $98 \%$ to the combination treatment, while the rest $(2 \%)$ were non-responding as shown in figure (19). 


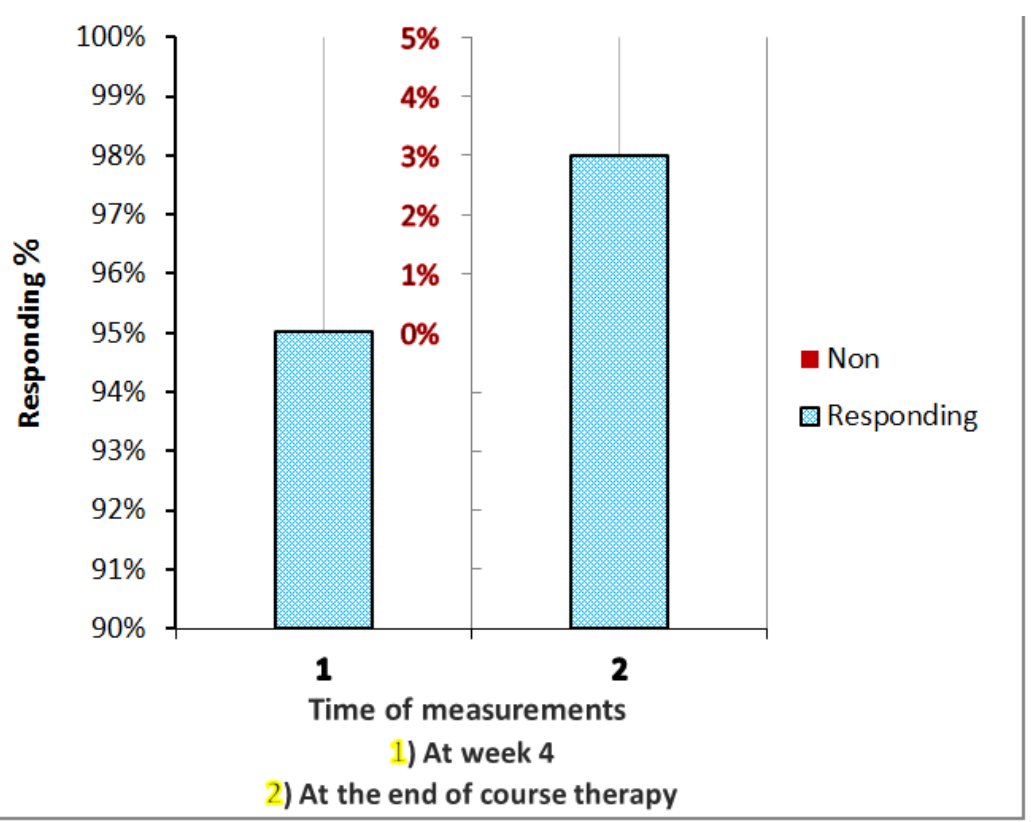

Figure 19. Comparison between responding, non-responding patients during and after treatment

\section{Correlation study}

After the end of course therapy, the correlation among measurements was studied. The present study showed a positive correlation between PCR in responding and non-responding patients as well as, a positive correlation of BIL between two groups of patients, as shown in figures (20 and 21). Also, PLT between responding and non-responding patients showed the same type of correlation, as shown in figure (22).

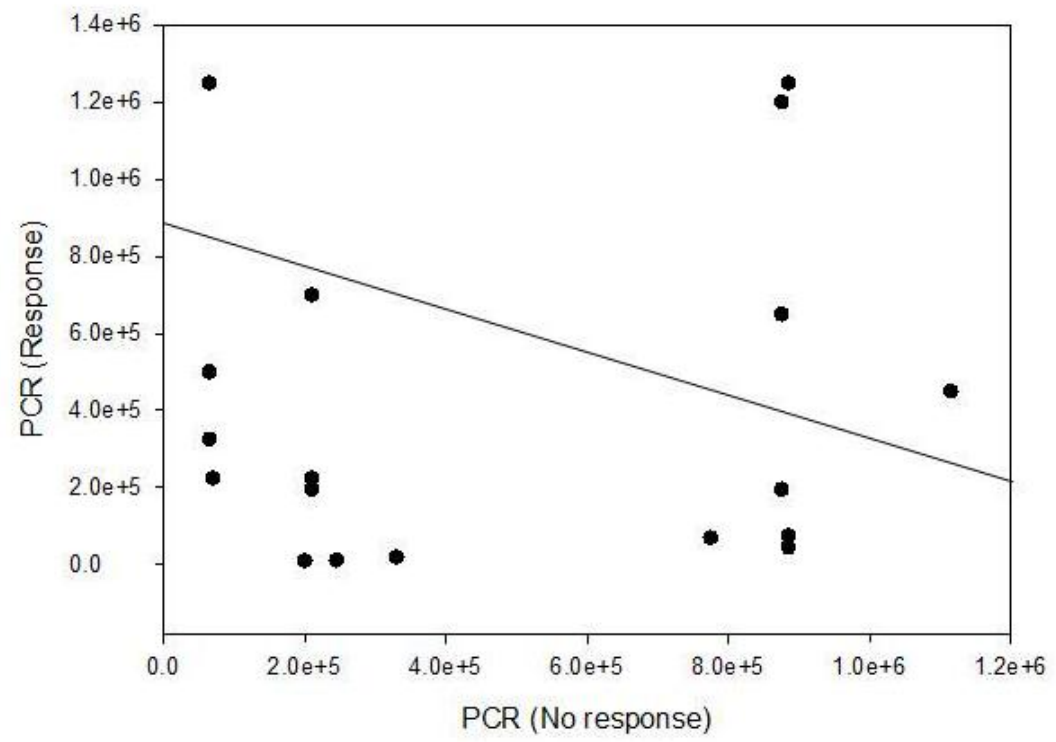

Figure 20. Linear Pearson Correlation between PCR response, PCR no response 


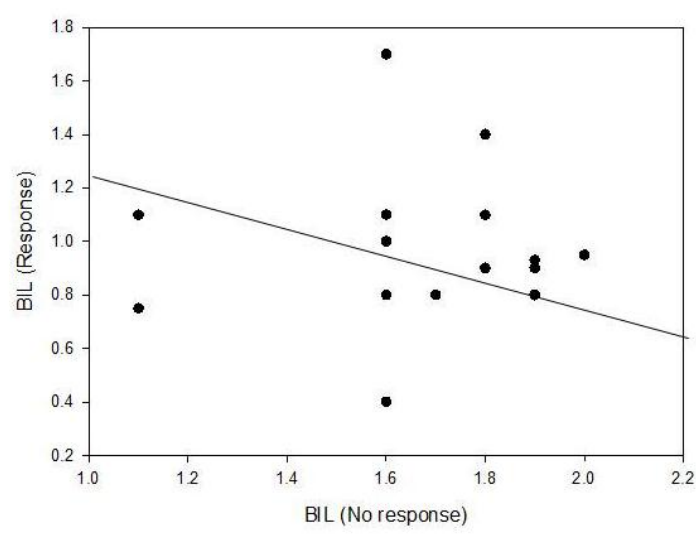

Figure 21. Linear Pearson Correlation between BIL response, BIL no response

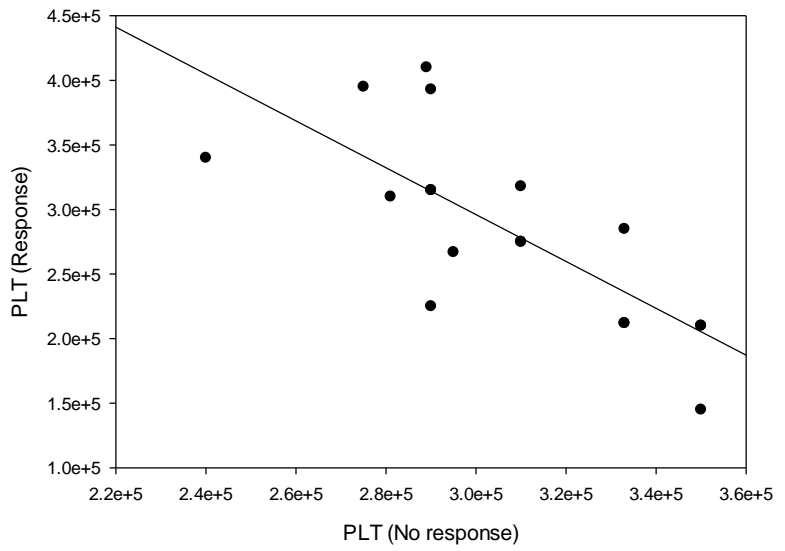

Figure 22. Linear Pearson Correlation between PLT response, PLT no response

While, this study showed that, there was no correlation between Hb, TLC, ALT between responding and non-responding patients as shown in figures $(23,24 \& 25)$.

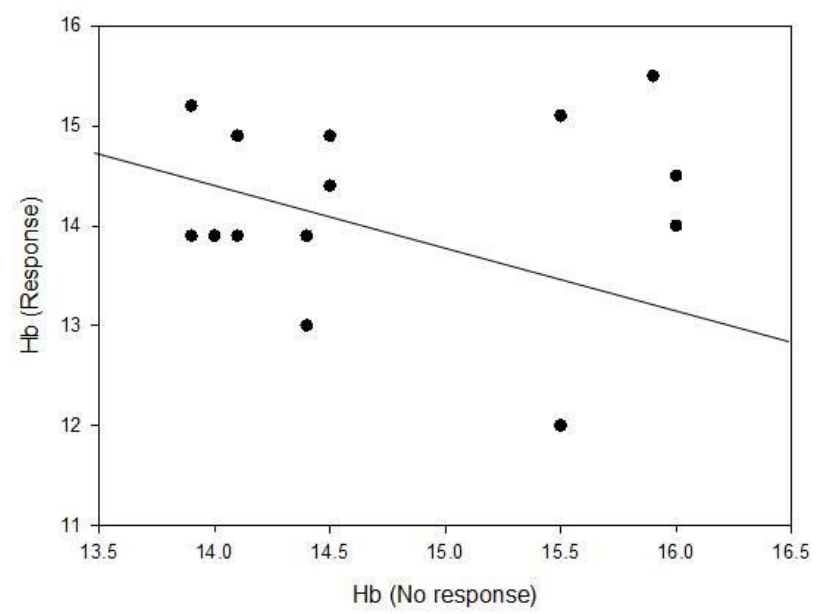

Figure 23. Linear Pearson Correlation between $\mathrm{Hb}$ no response, $\mathrm{Hb}$ response 


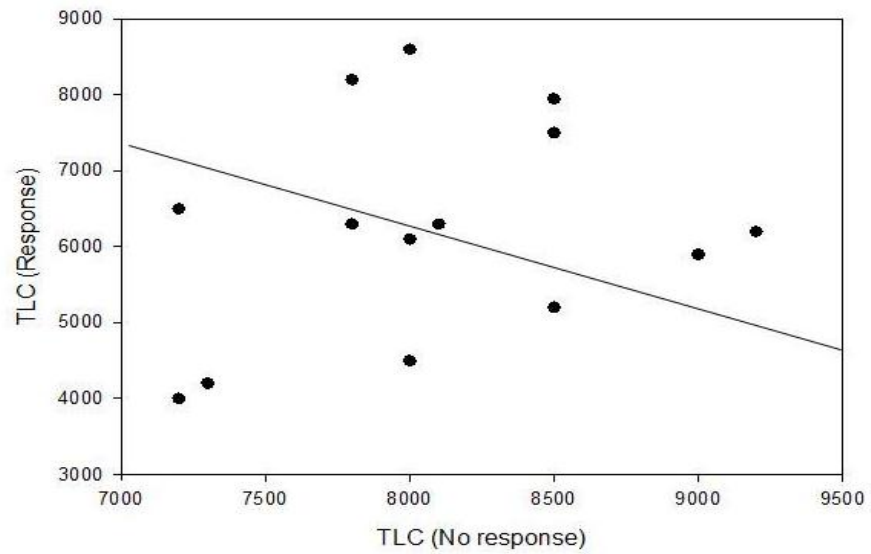

Figure 24. Linear Pearson Correlation between TLC no response, TLC response

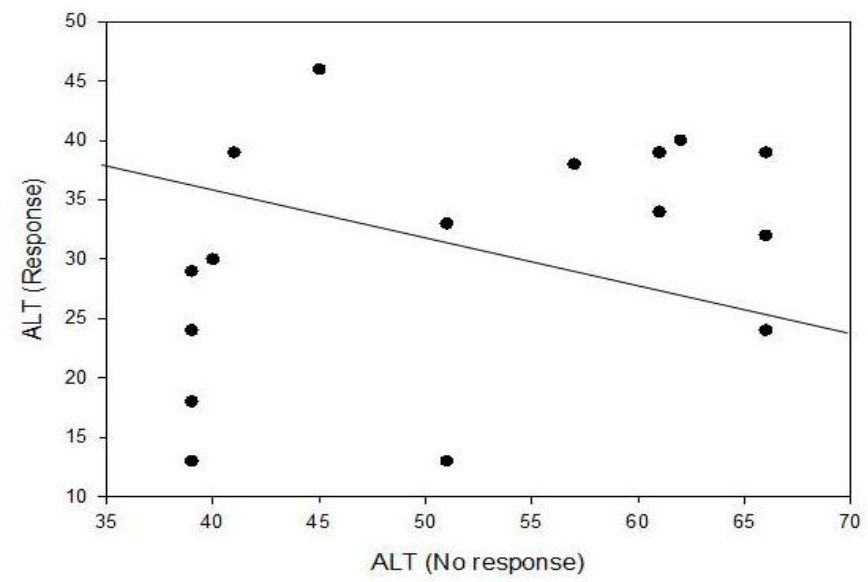

Figure 25. Linear Pearson Correlation between ALT no response, ALT response

As well as, the current study showed that, there was a negative correlation between AST, ALB of response patients and no response as shown in figures ( $26 \& 27$ ).

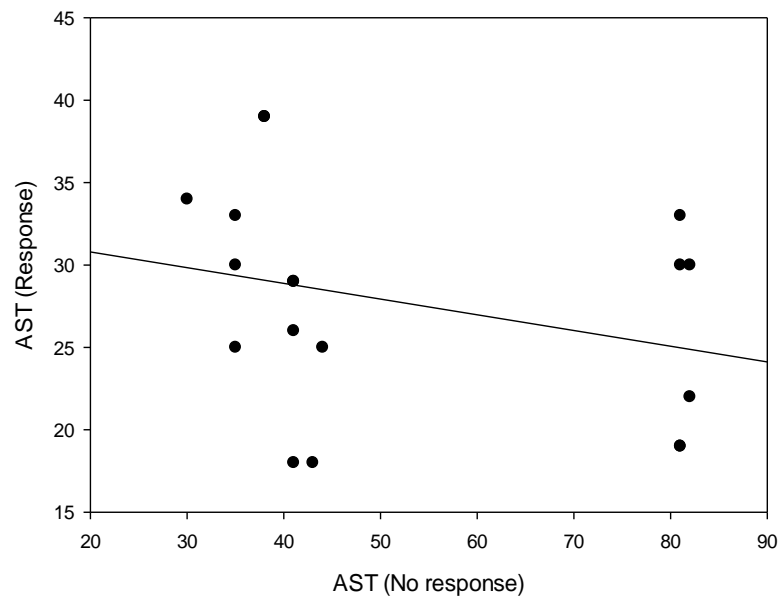

Figure 26. Linear Pearson Correlation between AST response, AST no response 


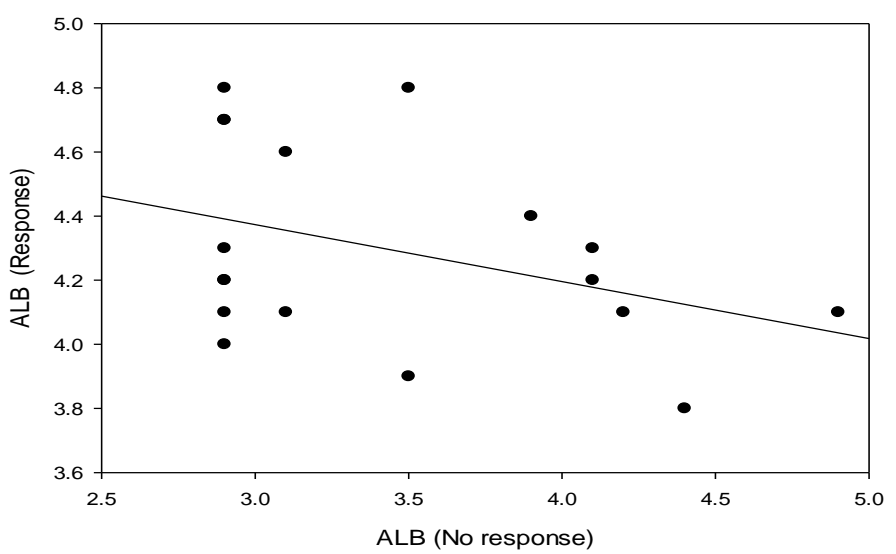

Figure 27. Linear Pearson Correlation between ALB no response, ALB response

\section{Discussion}

In Egypt, HCV and its related complications are the most endemic problem. The infection percentage between Egyptian populations is the highest compared to any other population in the world (El-Zanaty and Way 2009; Shepard et al., 2005;Omran et al., 2018). In the early stages of HCV infections, an accurate and sensitive diagnosis is important for the appropriate treatment (Simmonds et al. 2005). Daclatasvir drug is an NS5A inhibitor with pharmacokinetic profile with a once-daily dose (Pol et al. 2016). Daclatasvir is well tolerated with some mild side effects like a headache, which frequently occur (Pol et al. 2016). Another pan-genotyping effective and tolerable NS5B inhibitor is Sofosbuvir drug with oral dosing one time daily for 12 weeks. These drugs are more specific to HCV particles, and its mechanism of action depends on attacking the viral enzymes system responsible for RNA replication process, thereby inhibiting viral multiplication (Muir 2014). Therefore, the evaluation of biochemical and viral measurements during this therapy course may be used as a predictive result for evaluation of efficacy and expecting responder and non-responder patients. In our study, there was a marked decrease in liver enzymes occurred after 4 weeks of the treatment. ALT was entirely improved in some patients' samples and these patients classified as responders, but other samples were in abnormal ranges, and therefore are considered as non-responding, and these results are in consistency with Deterding et al. (2015). AST decreased significantly at week 4 of treatment with target combination used in this study and returned to normal range in responder, but in abnormal values in other patient samples and they considered as non-responders and this trend of results are in complete accordance with the study published by Elsharkawy et al. (2018). This improvement in the liver enzymes was maintained until 12 weeks after the treatment. Infected patients with chronic HCV have abnormal serum liver enzyme levels most of the time; this occurs when liver cells are damaged, ALT and AST (proteins made by liver cells) leak out into the bloodstream and the level of these enzymes in the blood is higher than normal. However, the levels can fluctuate between normal and abnormal throughout the disease (Forns et al. 2002; Greenslade 2009). It was found that bilirubin is close to the normal range by week 4 of therapy in patients' samples who are responders, and complete normalization was achieved by end-of-treatment course. Normalization of serum bilirubin by this combination of therapy, as shown by our results, are in 
agreement with the study by (Mohamed et al. 2017) In addition, levels of bilirubin in the blood raises and decrease in patients with hepatitis $\mathrm{C}$ where bilirubin levels are usually normal until a significant amount of liver damage has occurred (El Guiniady et al. 1994). Moreover, backward leakage or decreased excretion of the pigment results in elevation of the serum total bilirubin level in a patient suffering from chronic viral hepatitis. As well as, INR value exhibited improvement during treatment in responding patients and with a slight elevation in non-responder but completely recover after a complete course of treatment in responders. After the course of the treatment, biochemical, and viral measurements of the blood samples from all patients were determined. Liver enzymes and viral load showed response which ultimately achieved in $98 \%$ of patients in a complete normalization ranges, and viral titer reached to the below detection limit. On the other hand, biochemical and viral values in nonresponding patients still abnormal with a marked abnormality in all biochemical functions and viral titer. In the same direction, our results were consistency with Fontaine et al. (2015) who found the same rate of SVR after using of this combination (SOF/DAC) in genotype 4 for 12 weeks. Also, their study gives us an indication of the efficacy of this combination therapy in managing HCV patients (Fontaine et al. 2015). This percentage of response is supported by another study in Egypt which included 18,000 infected patients with HCV they were a high rate of SVR reach to 95\%, and their study concluded that the drug combination used has a good effect in treating a chronic patient of HCV especially genotype 4 (Omar et al. 2018).

\section{Conclusion}

A necessary approach is to come to know and identify early non-responding patients during treatment. Which leads to saving of medical costs, and the most important is to guide these patients by their physicians for appropriate treatment and not to waste time so as not to worsen their health. In this study, we use the elevated liver enzymes and other biochemical and viral characteristics at week 4 of treatment to predict responders and non-responders to SOF/DCV therapy. The predictive value of response was $95 \%$, while non-responders was 5\%. On the other hand, the results of the confirmatory measurements after completion of the full course of SOF/DCV therapy (week12) gives complete response value was $98 \%$, while the non-responders were $2 \%$. Thus, depending on the findings of our results, testing for biochemical especially ALT and HCV RNA during week 4 SOF/DCV therapy, it can give us a predictive result of the extent of response, in addition, it is practical and beneficial to patients.

\section{REFERENCES}

Abd-Elsalam S, Sharaf-Eldin M, Soliman S, Elfert A, Badawi R, Ahmad YK (2017) Efficacy and safety of sofosbuvir plus ribavirin for treatment of cirrhotic patients with genotype 4 hepatitis $\mathrm{C}$ virus in real-life clinical practice. Archives of Virology 163:51-56. doi:10.1007/s00705-017-3573-0

Ali S, Ali I, Azam S, Ahmad B (2011) Frequency distribution of HCV genotypes among chronic hepatitis $\mathrm{C}$ patients of Khyber Pakhtunkhwa. Virology Journal 8:193. doi:10.1186/1743-422x-8-193

Ballester JM et al. (2005) Hepatitis C virus antibodies and other markers ofbloodtransfusion-transmitted infection in multi-transfused Cuban patients. Journal of Clinical Virology 34:S39-S46. doi:10.1016/s1386-6532(05)80033-2 
Blach S et al. (2017) Global prevalence and genotype distribution of hepatitis $\mathrm{C}$ virus infection in 2015: a modelling study. The Lancet Gastroenterology \& Hepatology 2:161-176. doi:10.1016/s2468-1253(16)30181-9

Burits A et al (1999). Tietz Textbook of clinical chemistry, 3 rd ed AACC .

Courouce AM (1998) Development of screening and confirmation tests for antibodies to hepatitis $\mathrm{C}$ virus. Current studies in hematology and blood transfusion:64-75.

Cox AL (2015) Global control of hepatitis C virus. Science 349:790-791. doi:10.1126/science.aad1302

Deterding K et al. (2015) Improvement of liver function parameters in advanced HCVassociated liver cirrhosis by IFN-free antiviral therapies. Alimentary Pharmacology \& Therapeutics 42:889-901. doi:10.1111/apt.13343

El-Zanaty F, Way A (2009) Egypt demographic and health survey 2008. Cairo, Egypt: Ministry of Health, El-Zanaty and Associates, and Macro International.

El Guiniady MA, Metwally A, Abdel-Bary MA, Abdel-Fatah SA, El Touny MA (1994) Clinical and pharmacokinetic study of praziquantel in Egyptian schistosomiasis patients with and without liver cell failure. The American Journal of Tropical Medicine and Hygiene 51:809-818. doi:10.4269/ajtmh.1994.51.809

Elsharkawy A et al. (2018) Planning and prioritizing direct-acting antivirals treatment for HCV patients in countries with limited resources: Lessons from the Egyptian experience. Journal of Hepatology 68:691-698. doi:10.1016/j.jhep.2017.11.034

Fontaine $\mathrm{H}$ et al. (2015) LP28 : Efficacy of the oral sofosbuvir-based combinations in $\mathrm{HCV}$ genotype 4-mono-infected patients from the french observational cohort anrs CO22 hepather. Journal of Hepatology 62:S278. doi:10.1016/s0168$8278(15) 30182-3$

Forns $\mathrm{X}$ et al. (2002) Identification of chronic hepatitis $\mathrm{C}$ patients without hepatic fibrosis by a simple predictive model. Hepatology 36:986-992. doi:10.1053/jhep.2002.36128

Gendler S . Uric acid .Kaplan A et al .Clin Chem The C.V. Mosby Co .St louis .Toronto .Princeton 1984; 1268- 1273 and 425 . Gastaminza P, Kapadia SB, Chisari FV( 2006) . Differential biophysical properties of infectious intracellular and secreted hepatitis C virus particles. 80:11074-11081.

Greenslade L (2009) Assessment of liver Function and diagnostic studies.: Liver Diseases: An essential guide for nurses and health care professionals, 15-31. doi:10.1002/9781444322682.ch2

Hoofnagle JH (1997) Hepatitis C: The clinical spectrum of disease. Hepatology 26:15S-20S. doi:10.1002/hep.510260703

Kamal SM, Nasser IA (2008) Hepatitis C genotype 4: What we know and what we don't yet know. Hepatology 47:1371-1383. doi:10.1002/hep.22127

Kim CW, Chang K-M (2013) Hepatitis C virus: virology and life cycle. Clinical and Molecular Hepatology 19:17-25. doi:10.3350/cmh.2013.19.1.17 
Kleiber J, Walter T, Haberhausen G, Tsang S, Babiel R, Rosenstraus M (2000) Performance characteristics of a quantitative, homogeneous TaqMan RT-PCR test for HCV RNA. The Journal of Molecular Diagnostics 2:158-166. doi:10.1016/s1525-1578(10)60632-0

Lavanchy D (2011) Evolving epidemiology of hepatitis C virus. Clinical Microbiology and Infection 17:107-115. doi:10.1111/j.1469-0691.2010.03432.x

Mohamed MS, Hanafy AS, Bassiony MAA, Hussein S (2017) Sofosbuvir and daclatasvir plus ribavirin treatment improve liver function parameters and clinical outcomes in Egyptian chronic hepatitis C patients. European Journal of Gastroenterology \& Hepatology 29:1368-1372. doi:10.1097/meg.0000000000000963

Mohamoud YA, Mumtaz GR, Riome S, Miller D, Abu-Raddad LJ (2013) The epidemiology of hepatitis C virus in Egypt: a systematic review and data synthesis. BMC Infectious Diseases 13:288. doi:10.1186/1471-2334-13-288

Muir AJ (2014) The rapid evolution of treatment strategies for hepatitis C. American Journal of Gastroenterology 109:628-635. doi:10.1038/ajg.2014.66

Omar $\mathbf{H}$ et al. (2018) Generic daclatasvir plus sofosbuvir, with or without ribavirin, in treatment of chronic hepatitis C: real-world results from 18378 patients in Egypt. Alimentary Pharmacology \& Therapeutics 47:421-431. doi:10.1111/apt.14428

Omran D et al. (2018) Towards hepatitis C virus elimination: Egyptian experience, achievements and limitations. World Journal of Gastroenterology 24:4330-4340. doi:10.3748/wjg.v24.i38.4330

Pol S, Vallet-Pichard A, Corouge M (2016) Daclatasvir-sofosbuvir combination therapy with or without ribavirin for hepatitis $\mathrm{C}$ virus infection: from the clinical trials to real life. Hepatic Medicine: Evidence and Research 8:21-26. doi:10.2147/hmer.s62014

Ruane PJ et al. (2015) Sofosbuvir plus ribavirin for the treatment of chronic genotype 4 hepatitis $\mathrm{C}$ virus infection in patients of Egyptian ancestry. Journal of Hepatology 62:1040-1046. doi:10.1016/j.jhep.2014.10.044

Reitman, A. and Frankel, S. ( 1957) : Amer J. Clin. Path ., 28 : 56.

Shepard CW, Finelli L, Alter MJ (2005) Global epidemiology of hepatitis C virus infection. The Lancet Infectious Diseases 5:558-567. doi:10.1016/s14733099(05)70216-4

Simmonds P et al. (2017) ICTV virus taxonomy profile: Flaviviridae. Journal of General Virology 98:2-3. doi:10.1099/jgv.0.000672

Simmonds $\mathbf{P}$ et al. (2005) Consensus proposals for a unified system of nomenclature of hepatitis C virus genotypes. Hepatology 42:962-973. doi:10.1002/hep.20819

Struthers A (2007) From schistosomiasis to hepatitis C: the spread of HCV in Egypt. Medical Journal of Therapeutics Africa 1:213-221. 
Sulkowski MS et al. (2014) Daclatasvir plus sofosbuvir for previously treated or untreated chronic HCV infection. New England Journal of Medicine 370:211221. doi:10.1056/NEJMoa1306218

Wagner C, Dati F (1998), prothrombin time (PT) test in :Thomas L, ed. clinical laboratory diagnostics . Frankkfurt : TH - Books verlagsgesellschaft ;: 599-601

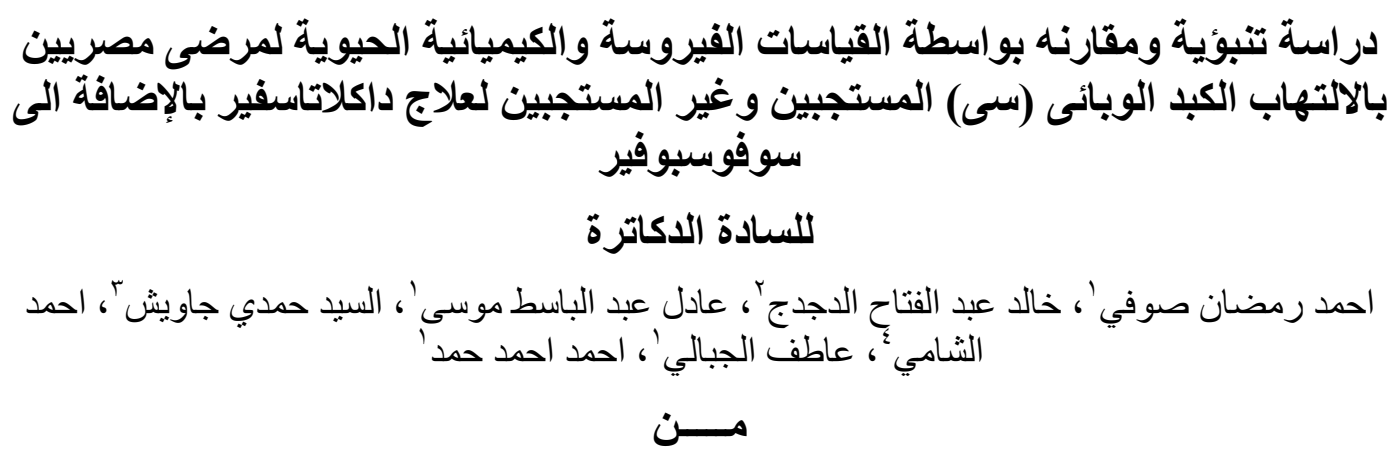

$$
\text { الملخص العربي }
$$

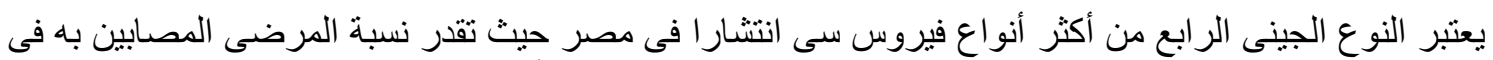

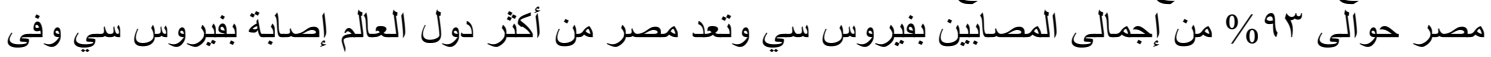

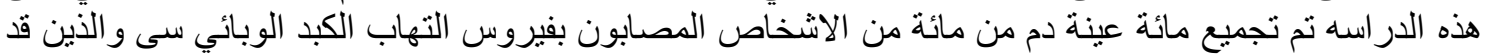
أعطو نتائج تحاليل موجبه بواسطة الإليزا (ELISA) كما كانت منوسط نسب (RT-PCR) تساوى

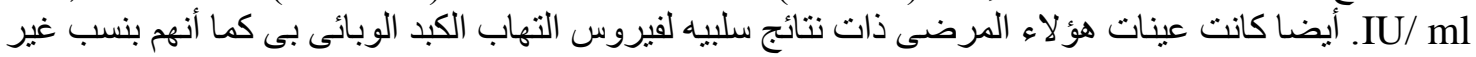

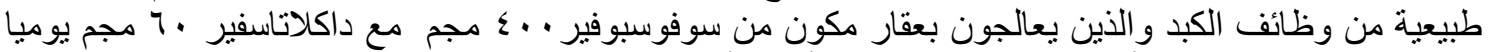

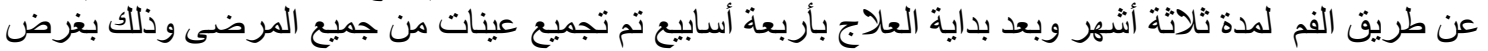

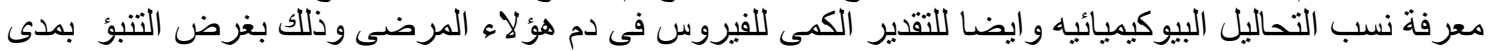

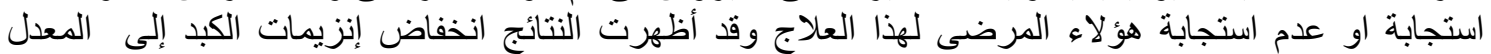

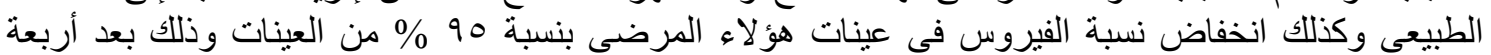

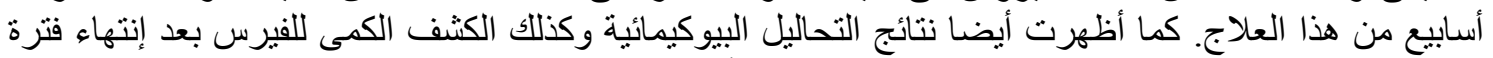

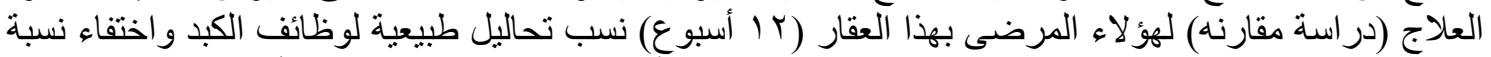

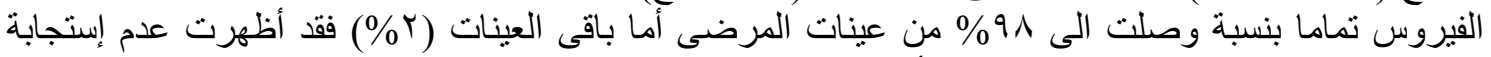

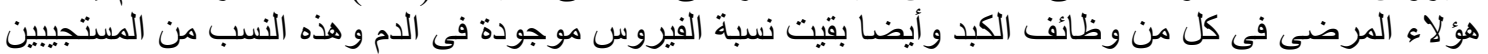
و غير المستجييين تؤكد الدر اسات السابقه التى قد تمت على نفس العقار المستخدم. 